\title{
Assessment of dependence and anxiety among benzodiazepine users in a provincial municipality in Rio Grande do Sul, Brazil
}

\author{
Avaliação da dependência e da ansiedade em usuários de benzodiazepínicos \\ em um município do interior do Rio Grande do Sul
}

Janaína Barden Schallemberger, ${ }^{1}$ Christiane de Fátima Colet $^{2}$

\begin{abstract}
Introduction: Benzodiazepines are among the most prescribed drugs for anxiety and one of the most used drug classes in the world and have a high potential for addiction. The objective of this study was to assess levels of dependence and anxiety among users of these drugs in the public health system.

Methods: This was a cross-sectional, descriptive and quantitative study. Benzodiazepine users treated on the public health system were selected. Anxiety levels were assessed with the Hamilton Anxiety Scale and dependency with the Benzodiazepine Dependence Self-Report Questionnaire.

Results: Benzodiazepine use was higher among women and in older age groups. Duration of benzodiazepine use was greater than 1 year for all respondents. The dependence assessment indicated that more than half of users were dependent on taking benzodiazepines and most had a severe degree of anxiety.

Conclusion: This study found evidence of prolonged and inappropriate use of benzodiazepines. It is necessary to educate users about the risks of these drugs and to develop strategies to rationalize use of these drugs by working with prescribers and dispensers. Keywords: Benzodiazepines, anxiety, dependency, primary care.
\end{abstract}

\section{Resumo}

Introdução: Os benzodiazepínicos estão entre os medicamentos mais prescritos para ansiedade, e entre as classes farmacológicas mais utilizadas no mundo, apresentando alto potencial de dependência. $O$ objetivo deste estudo foi verificar o nível de dependência e ansiedade entre os usuários desses medicamentos no sistema público de saúde.

Métodos: Trata-se de um estudo transversal, descritivo, quantitativo. Foram selecionados os usuários de benzodiazepínicos tratados no Sistema Único de Saúde. O nível de ansiedade foi avaliado pela Escala de Avaliação da Ansiedade de Hamilton, e a dependência pelo Benzodiazepine Dependence Self-Report Questionnaire.

Resultados: A utilização de benzodiazepínicos foi superior entre mulheres e em faixas etárias mais elevadas. O período de utilização do benzodiazepínico foi maior que 1 ano para todos os entrevistados. A avaliação da dependência constatou-se que mais da metade dos usuários eram dependentes do uso de benzodiazepínicos, e a maioria apresentou grau de ansiedade grave.

Conclusões: $O$ uso prolongado e inadequado de benzodiazepínicos ficou evidente neste estudo. É necessário conscientizar os usuários sobre os riscos desses medicamentos, bem como desenvolver estratégias para racionalizar seu uso, abordando prescritores e dispensadores.

Descritores: Benzodiazepínicos, ansiedade, dependência, atenção primária.

\footnotetext{
1 Universidade Regional do Noroeste do Estado do Rio Grande do Sul (UNIJUÍ), Ijuí, RS, Brazil. ${ }^{2}$ Departamento de Ciências da Vida (DCVida), UNIJUÍ, Ijuí, RS, Brazil. This paper was presented as a monograph at the School of Pharmacy at UNIJUÍ, Ijuí, RS, Brazil.

Financial support: none.

Submitted Jul 27 2015, accepted for publication Nov 16 2015. No conflicts of interest declared concerning the publication of this article.

Suggested citation: Schallemberger JB, Colet CF. Assessment of dependence and anxiety among benzodiazepine users in a provincial municipality in Rio Grande do Sul, Brazil. Trends Psychiatry Psychother. 2016;38(2):63-70. http://dx.doi.org/10.1590/2237-6089-2015-0041
} 


\section{Introduction}

Benzodiazepines (BDZ) are the most widely used drugs for anxiety because of their anxiolytic and hypnotic effects. Some variants also have anticonvulsant and muscle relaxant activity. ${ }^{1}$ Because of their multiple uses, BDZ are among the most prescribed drugs in the world and are taken by about $4 \%$ of the population. ${ }^{2}$

In Brazil, BDZ are also among the most commonly used drug classes, according to the II Home Survey on the use of psychotropic drugs in Brazil (2005). This survey was conducted with 7,939 respondents in 108 Brazilian cities with more than 200,000 inhabitants and $5.6 \%$ of respondents reported $\mathrm{BDZ}$ use. ${ }^{3}$ Consumption of $\mathrm{BDZ}$ is becoming a public health problem because of often indiscriminate use. ${ }^{4}$ Another factor that may favor increased use of BDZ is free distribution by the public health system, since this makes them accessible to a large population, and is associated with a lack of protocols to guide prescribing and dispensing. ${ }^{5}$

Benzodiazepines have a high potential for addiction, ${ }^{6}$ which is related to their pharmacokinetics. ${ }^{7}$ The higher the lipid solubility and lower the half-life, the greater the potential for drug dependence, and since lipid solubility is what determines the absorption rate and the speed and extent of drug delivery, it is an important feature of BDZ, which have good tissue distribution and cross the blood-brain barrier easily. ${ }^{8}$ Furthermore, these drugs can cause tolerance and other adverse events, increasing the risk of morbidity and mortality and raising health care costs. ${ }^{9}$

Although BDZ are safer than other classes of drugs used for the same therapeutic purposes, their use must be monitored due to the high incidence of side effects ${ }^{10}$ including drowsiness, confusion, impaired psychomotor activity, memory impairment, tolerance and dependence, in addition to potentiation of the depressant effect by interaction with other depressant drugs, such as alcohol. ${ }^{1}$

Assessment of dependence on BDZ has been conducted by international and Brazilian studies, such as the II Home Survey on the use of psychotropic drugs in Brazil (2005), which reported that $0.5 \%$ of respondents had a BDZ addiction. ${ }^{3} \mathrm{~A}$ home study in China involving 3,000 families found 107 were dependent on BDZ, 91.6\% of whom acquired their medicines by prescription. ${ }^{11}$ However, no studies have been carried out in Brazil to assess anxiety in BDZ users, which is a differentiating factor in the present study's approach.

In view of the lack of studies assessing dependence and anxiety among users of BDZ and their risks, this study aims to determine levels of dependence and anxiety among continuous users of these drugs on the public health system and the indications for their prescription.

\section{Method}

This is a cross-sectional, descriptive and quantitative study, which was conducted in two stages:

1) The dispensing pharmacy at the Saldanha Marinho municipal health center maintains a database of the drugs it dispenses. In December 2014, this database was queried to identify users to whom BDZ were dispensed between January and August 2014, and select those who had received at least three dispensations during this period.

2) All users selected were visited. Data collection was conducted from January to February 2015, with the aid of a semi-structured questionnaire containing questions related to socioeconomic characteristics and BDZ use, such as duration of use, self-reported side effects and the presence of concomitant diseases. Additionally, two validated questionnaires were administered: 1) the Hamilton Anxiety Scale ${ }^{12}$ and 2) the Benzodiazepine Dependence Self-Report Questionnaire, ${ }^{13}$ which assesses dependence.

The Hamilton Anxiety Scale comprises 14 items and the total score ranges from 0 to 56 , classified as follows: a) less than 8: normal; b) from 9 to 15 : mild anxiety; c) 16 to 25: moderate anxiety; d) greater than 26: severe anxiety. The Benzodiazepine Dependence Self-Report Questionnaire generates raw scores ranging from 15 to 75 for users who claim they have not tried to stop taking BDZ, while values can vary from 20 to 100 for respondents who have tried to stop. Scores are classified as follows: a) 30 points or fewer: not dependent; b) 31 to 50 points: potentially dependent; c) more than 51 points: dependent. Furthermore, these scores are dichotomized for evaluation of subscale ratings, with raw scores transformed as follows: 1 and 2 are graded as 0 and 3, 4 and 5 are graded as 1 . The sums of dichotomized scores for each of four subscales, problematic use, preoccupation, lack of compliance and withdrawal, are then classified as follows $0=$ very low, $1=$ moderate, 2 = high, and 3, 4 and 5 = very high.

Antidepressants were categorized by pharmacological class according to the fourth level of the Anatomical Therapeutic Chemical Code (ATC).${ }^{14}$

The variables collected using the semi-structured questionnaire were subjected to simple descriptive analysis, with calculation of mean frequencies and standard deviations. Data were stored in a database using the Statistical Package for Social Sciences (version 18.0). 
This study was approved by the Ethics Committee at the Universidade Regional do Noroeste do Estado do Rio Grande do Sul (UNIJUÍ), Brazil (protocol no. 878.442).

\section{Results}

The sample comprised $42 \mathrm{BDZ}$ users, $76.2 \%$ of whom were female, as shown in Table 1.

The BDZ presentations dispensed at the community health center were as follows: a) clonazepam pharmaceutical oral solution $(2.5 \mathrm{mg} / \mathrm{mL})$ or pills (2 $\mathrm{mg}$ ); b) diazepam pills ( $5 \mathrm{mg}$ and $10 \mathrm{mg}$ ). The most common BDZ presentation used in this study was $2.5 \mathrm{mg}$ clonazepam/mL (52.4\%), followed by diazepam $10 \mathrm{mg}$, prescribed to $33.3 \%$ (Table 2).

As shown in Table 3, none of the users reported using BDZ for a period of less than 1 year. Most (61.9\%) had been taking them for 1 to 5 years and the mean duration was 6.5 years ( \pm 6.47 ). The most often cited first prescriber was a general practitioner (76.2\%), followed by a neurologist $(11.9 \%)$. The most frequent indications were insomnia (71.4\%) and anxiety (28.6\%).

The results of the Hamilton Anxiety Scale assessments demonstrated that most patients had a severe degree of anxiety $(47.66 \%)$, followed by moderate $(26.2 \%)$ and mild anxiety (19.04\%) (Table 4).

The most frequently reported diseases were hypertension $(69 \%)$, depression $(31 \%)$ and diabetes (12\%). Notwithstanding, $60 \%$ of the patients reported taking antidepressants and the most commonly used classes were selective serotonin reuptake inhibitors with $56 \%$, followed by nonselective monoamine oxidase inhibitors with $40 \%$.

Table 1 - Demographic characteristics of benzodiazepine users on the public health system in Saldanha Marinho, RS, Brazil, 2015 ( $n=42)$

\begin{tabular}{lc}
\hline Variables & $\mathbf{n}(\mathbf{\%})$ \\
\hline Sex & $32(76.2)$ \\
Female & $10(23.8)$ \\
Male & \\
Age & $5(11.9)$ \\
$30-45$ years & $17(40.5)$ \\
$46-59$ years & $20(47.6)$ \\
$\geq 60$ & \\
Educational level & $31(73.8)$ \\
Did not complete primary education & $2(4.8)$ \\
Completed primary education & $7(16.6)$ \\
Secondary education & $1(2.4)$ \\
Started but not completed higher education & $1(2.4)$ \\
Illiterate & \\
Marital status & $12(28.6)$ \\
Not married & $20(47.6)$ \\
Married & $9(21.4)$ \\
Widower & $1(2.4)$ \\
Divorced & \\
Living alone & $33(78.6)$ \\
No & $9(21.4)$ \\
Yes & \\
\hline
\end{tabular}

Table 2 - Benzodiazepines dispensed by the public health system in Saldanha Marinho, RS, Brazil, and their mean doses, $2015(n=42)$

\begin{tabular}{lcc}
\hline Benzodiazepines used & $\mathbf{n}(\%)$ & Mean dose (mg) \pm standard deviation \\
\hline Clonazepam & & $1 \pm 0.49$ \\
$2.5 \mathrm{mg} / \mathrm{mL}$ & $22(52.4)$ & $3.2 \pm 1.09$ \\
$2 \mathrm{mg}$ & $6(4.3)$ & 5 \\
Diazepam & $1(2.4)$ & 10 \\
$5 \mathrm{mg}$ & $14(33.3)$ & \\
$10 \mathrm{mg}$ &
\end{tabular}


Table 3 - Total duration of use and first prescriber of benzodiazepines dispensed by the public health system in Saldanha Marinho, RS, Brazil, 2015 ( $n=42$ )

\begin{tabular}{lc}
\hline Variables & $\mathbf{n ~ ( \% )}$ \\
\hline Duration of use & $26(61.9)$ \\
$1-5$ years & $10(23.8)$ \\
$6-10$ years & $4(9.5)$ \\
$11-20$ years & $2(4.8)$ \\
$>20$ years & $32(76.2)$ \\
First prescriber & $5(11.9)$ \\
General practitioner & $3(7.1)$ \\
Neurologist & $1(2.4)$ \\
Psychiatrist & $1(2.4)$ \\
Cardiologist & \\
Pulmonologist & \\
\hline
\end{tabular}

Table 4 - Hamilton Anxiety Scale, $2015(n=42)$

\begin{tabular}{lc}
\hline Degree of anxiety & $\mathbf{n ~ ( \% )}$ \\
\hline Severe $(>25)$ & $20(47.66)$ \\
Moderate $(16-25)$ & $11(26.2)$ \\
Slight $(9-15)$ & $8(19.04)$ \\
Normal $(<8)$ & $3(7.1)$ \\
\hline
\end{tabular}

Table 5 - Evaluation of benzodiazepine dependence on the public health system in Saldanha Marinho, RS, Brazil, assessed using the Benzodiazepine Dependence Self-Report Questionnaire, $2015(\mathrm{n}=42)$

\begin{tabular}{|c|c|}
\hline Classification & n (\%) \\
\hline \multicolumn{2}{|l|}{ Entire sample $(n=42)$} \\
\hline Potentially dependent & $26(61.9)$ \\
\hline Dependent & $15(35.7)$ \\
\hline Not dependent & $1(2.4)$ \\
\hline \multicolumn{2}{|l|}{ Dichotomized scores $(n=42)$} \\
\hline \multicolumn{2}{|l|}{ Problematic use } \\
\hline Very low & $12(28.6)$ \\
\hline Moderate & $18(42.9)$ \\
\hline High & $8(19)$ \\
\hline Very high & $4(9.5)$ \\
\hline \multicolumn{2}{|l|}{ Preoccupation } \\
\hline Moderate & $3(7.1)$ \\
\hline High & $6(14.3)$ \\
\hline Very high & $33(78.6)$ \\
\hline \multicolumn{2}{|l|}{ Lack of compliance } \\
\hline Very low & $1(2.4)$ \\
\hline Moderate & $20(47.6)$ \\
\hline High & $13(31)$ \\
\hline Very high & 8 (19) \\
\hline \multicolumn{2}{|c|}{ Problems related to spontaneous withdrawal of BDZ $(n=21)$} \\
\hline Very low & $3(14.3)$ \\
\hline Moderate & $1(4.8)$ \\
\hline High & $5(23.8)$ \\
\hline Very high & $12(57.1)$ \\
\hline
\end{tabular}

66 - Trends Psychiatry Psychother. 2016;38(2) 
The age group containing most BDZ users was the over 60 s $(47.6 \%)$, followed by the $46-59$ years range $(40.5 \%)$, and the mean age of the sample was $60.7 \pm$ 13.6 years. The great majority of the sample reported that they had not completed primary education (73.8\%).

The most frequent marital status category was married, at $47.6 \%$, and $78.6 \%$ of users reported that they did not live alone (Table 1 ).

Drug dependence was assessed using the Benzodiazepine Dependence Self-Report Questionnaire. As shown in Table 5, 61.9\% of users were considered dependent and according to the dichotomized scores problematic use ratings were moderate for most users $(42.9 \%)$, Preoccupation was very high for $78.6 \%$ (33) of users and the lack of compliance was moderate for 20 $(47.6 \%)$ users and high for $13(31 \%)$.

There were a total of 42 respondents and 50\% (21) of them had attempted to stop taking BDZ. Within this subset, $57.1 \%$ (12) had had problems related to withdrawal of $B D Z$, with very high scores for the withdrawal subscale. Additionally, none of the users interviewed reported successfully withdrawing BDZ.

\section{Discussion}

There was a higher percentage of women than men among the BDZ users, which has also been demonstrated in several other studies. ${ }^{15-18}$ The greater frequency of $\mathrm{BDZ}$ use by women may be related to their higher prevalence of depression and anxiety. ${ }^{19}$ Additionally, women are less resistant to using medication, recognize disease symptoms, are more concerned with their health and more often seek health services than men. ${ }^{20-22}$

The predominant age group was elderly ( $\geq 60$ years), in common with the results of a study ${ }^{18}$ conducted with users of pharmacies at public sector primary care health centers in Ribeirão Preto (also in Brazil), which showed that a high proportion of BDZ users were aged from 61 to 70 .

This high proportion of BDZ use by older patients is inappropriate, because clonazepam and diazepam are long-acting drugs 1 and are not recommended for elderly patients since both have prolonged sedation periods, increasing the risk of falls and consequently of fractures. ${ }^{23,24}$ Furthermore, the half-life of BDZ can be tripled in elderly patients. ${ }^{10}$ When it is necessary to prescribe BDZ for these patients, drugs that are intermediate or short-acting are recommended, and even then at lower doses, ${ }^{24}$ such as, for instance, lorazepam and alprazolam. ${ }^{10}$ However, it is noteworthy that these drugs are not listed on the Municipal Register of Essential Medicines (REMUME) in the municipality studied, hindering patients' access to these products and creating a barrier to their prescription by physicians.

With regard to marital status, almost half the sample reported being married, which was also seen in other studies, ${ }^{25-27}$ in which patients in stable relationships exhibited greater BDZ use. This may be linked to increased worries and responsibilities related to the family. The results for educational level revealed that most had not finished primary education. Several other studies ${ }^{25-27}$ also suggest a positive association between less time in education and lower income and higher BDZ use. It has been shown that users with lower educational levels usually receive this type of treatment. ${ }^{25,27,28}$ One possible reason is limited access to non-drug therapies and the lack of complementary and integrative practices for the population that uses the Brazilian national health service (SUS), so clients end up resorting to prescribers at public sector primary care health centers, who, in turn, prescribe $\mathrm{BDZ}$ as the first choice therapy. The most widely used BDZ presentation was a $2.5 \mathrm{mg} / \mathrm{mL}$ clonazepam solution, which differs from the findings of other studies ${ }^{16-18,27}$ in which diazepam was the preferred BDZ. It is noteworthy that clonazepam was also prescribed in those studies, although to a lesser extent. The greater use of $2.5 \mathrm{mg}$ clonazepam $/ \mathrm{mL}$ seen in this study can be explained by the ease of dose adjustments and because this BDZ has a halflife that is somewhat shorter, compared to diazepam. ${ }^{29}$ However, many users may ignore the risk of dose increase since its pharmaceutical form is oral solution, considering them safer than pills, and guidance on this matter is the responsibility of health professionals. It is also noteworthy that both drugs are on both the REMUME and the National List of Essential Medicines (RENAME). ${ }^{29}$

The first prescriber for most users was their general practitioner, as was reported in another study, ${ }^{17}$ in which $80 \%$ of BDZ prescriptions were made by general practitioners. However, these professionals often do not feel comfortable dealing with mental illness and report difficulties. ${ }^{30}$ The lack of psychiatrists at primary care health centers could be one reason why most prescriptions are written by general practitioners. One of the functions of primary care is to resolve cases and small problems should be solved at the health center level and only when necessary should cases be referred to specialized care. ${ }^{31}$ Specialized care within the SUS for patients with mental health problems is provided by Centers for Psychosocial Care (CAPS), which offer various services such as psychotherapy, drug counseling and social support group activities. ${ }^{32}$ However, this service is not available in the city studied, and referral to a different municipality is required.

The main indication for taking BDZ was insomnia, followed by anxiety. These findings are consistent with 
descriptions in the literature and they are the main clinical uses of BDZ in psychiatry and general medical practice..$^{1,10}$ Note that insomnia is a symptom and not a disease, its association with anxiety is common and both are treated together with BDZ. ${ }^{10}$

The duration of BDZ use was greater than 1 year for all respondents in this study, with a long mean duration of use. One study ${ }^{33}$ has estimated that approximately 1 million people in the United Kingdom and about $2 \%$ of the adult population in the United States received a BDZ prescription for more than 12 months and $50 \%$ of these took the drugs for 5 years or more.

Use of BDZ for periods longer than six months is considered long term. This factor, as well as high doses, are characterized as risk factors for development of dependence and tolerance. 1,34,35 Prolonged use of BDZ can even cause manifestations of withdrawal, which can be confused with reappearance of the symptoms of anxiety. ${ }^{36}$ Given these risks, it is considered that the ideal treatment period is less than 6 months, which may decrease the risk of dependence and tolerance. As mentioned, all BDZ users in this study were taking them for more than six months and are potentially subject to tolerance and dependence, factors that were also assessed in this study.

The assessment of dependence on BDZ found that more than half of users did not meet the criteria for dependence on BDZ. Another study, ${ }^{37}$ also conducted in Brazil, indicated a much lower rate of dependency, since just $1.1 \%$ of 8,589 respondents from 107 Brazilian cities with more than 200,000 inhabitants met BDZ dependence criteria. Moreover, the figure was even lower in the Household Survey II on the use of psychotropic drugs in Brazil (2005), in which only $0.5 \%$ of 7,939 respondents from 108 Brazilian cities with more than 200,000 people exhibited dependence. ${ }^{3}$ Explanations for the difference between the present study and the others could be that the first one employed a different methodology for dependency assessment and that the high dependency rate in the present study could be related to the inclusion criteria of using BDZ for at least three months, since dependence can occur rapidly, after 4 to 6 weeks' use, and after 3 months of continuous use it affects the majority of patients. ${ }^{10}$

A study ${ }^{38}$ conducted in Nijmegen, in the Netherlands, examined 599 outpatient users of BDZ with the Benzodiazepine Dependence Self-Report Questionnaire, ${ }^{13}$ for which evaluation is based on mean scores and reported high levels of problematic use, and of problems related to withdrawal of $\mathrm{BDZ}$, while lack of compliance was considered low, i.e., patients adhered to the treatment. In the present study, most users had moderate scores for problematic use, scores for preoccupation were very high and lack of compliance scores were moderate.
The BDZ users were also assessed for degree of anxiety using the Hamilton Anxiety Scale ${ }^{12}$ and most had a severe degree of anxiety, despite taking BDZ. This can be explained by development of tolerance, since the users in this study had prolonged duration of use of these drugs. In contrast, a Spanish study ${ }^{39}$ that also used the Hamilton Anxiety Scale to evaluate anxiety in 27 patients with BDZ dependency (measured by the Structured Clinical Interview for DSM-IV Axis I Disorders [SCID-I]) and the mean Hamilton score was 16.4 points, which indicates a moderate degree of anxiety, but that study used the mean for the users and did not analyze the anxiety scales separately, as was done in this study.

Tolerance is the first observable result of chronic BDZ use. ${ }^{8}$ It is characterized by a decrease in pharmacological response and is possibly related to changes in relation to the receptors of these drugs. ${ }^{40}$ Repeated administration of the drug causes a shift of the dose-response curve to the right, so that higher doses/concentration of the drug are needed to produce the same effect, thus increasing the risk of BDZ users taking doses greater than those prescribed by their doctors. ${ }^{41}$

It is important to clarify that tolerance and withdrawal symptoms occur by reversible physiological adaptations to exposure to drugs and do not imply dependence, since it is known that people can exhibit dependence with no withdrawal symptoms and suffer withdrawal without being dependent. ${ }^{8}$

Most respondents reported taking antidepressants, but a smaller number reported having depression. However, in severe cases of anxiety, physicians often prescribe an antidepressant in conjunction with the $\mathrm{BDZ},{ }^{10}$ because many drugs used to treat depression also have an anxiolytic effect, including selective serotonin reuptake inhibitors, which was the class most used in combination with BDZ in another study, because they also treat the symptoms of anxiety. ${ }^{42}$ Non-selective monoamine oxidase inhibitors were the second most used class of antidepressants, which may be related to their sedative effect, making them useful for the treatment of depression mixed with anxiety. ${ }^{10}$

Additionally, another common indication for using antidepressants with BDZ is major depression. A multicenter study ${ }^{43}$ conducted in Japan found that approximately $60 \%$ of patients who consulted a psychiatrist for the first time for major depression were prescribed a BDZ in addition to an antidepressant. In the United States, one in three patients who were on pharmacological treatment with antidepressants used an anxiolytic simultaneously. ${ }^{43}$

Concomitant use of an anxiolytic antidepressant in initial therapy is often necessary because the acute depression phase is accompanied by irritability, anxiety 
and insomnia. Furthermore, the onset of antidepressant effect is slow, and there may be a worsening of depressive symptoms in the early days. ${ }^{44}$ Therefore, BDZ can be used concurrently for the first week, during the antidepressant latency period. ${ }^{45}$

With regard to attempts to interrupt use of $\mathrm{BDZ}, 50 \%$ reported discontinuing use of the $\mathrm{BDZ}$, which somewhat indicates knowledge about the consequences of prolonged use of these drugs. However, there was a high rate of problems, with patients feeling depressed, tired, upset, angry and restless and none of them succeeded. The most frequent problems with withdrawal of BDZ involve three types of syndromes: recurrence, in which the symptoms of the disease return, rebound, which is characterized by a return of the symptoms of the disease at a higher intensity, and withdrawal, in which new symptoms appear that can range from tremors, nausea, vomiting, anxiety and irritability to tonic-clonic seizures and hallucinations. ${ }^{8}$ Gradual withdrawal of BDZ is therefore recommended, even in patients on therapeutic doses, to relieve symptoms such as those mentioned above. ${ }^{46}$

Inappropriate use of BDZ is becoming a cause for concern and it is necessary to rationalize excessive use of these drugs, which over time have been growing into a public health problem. When indicated, prescriptions must be set within the lower therapeutic doses and for the shortest time possible, not exceeding 6 months of treatment. ${ }^{47}$ Furthermore, health professionals should be advised to inform patients about the consequences for their quality of life of incorrect BDZ use, and to take precautions that minimize the complications arising from the use of these drugs. ${ }^{17}$

\section{Conclusion}

This study has highlighted prolonged and inappropriate use of BDZ, which is becoming a public health problem. Furthermore, the growth in consumption of BDZ demonstrates a need to raise awareness about rational use of these drugs among the public and among the professionals involved.

Primary care health centers should run support groups for these patients, which would encourage reduced usage of BDZ and should encourage participation in nonpharmacological measures such as mental health groups, consultations with psychologists and alternative therapies, to thereby reduce use of these drugs and the problems related to them, such as dependence and tolerance.

There is a need for debate on the problems reported in this study, to seek strategies to address them.

\section{References}

1. Clark M, Finkel R, Rey J, Whalen K. Farmacologia ilustrada. $5^{a}$ ed. Porto Alegre: Artmed; 2013.

2. Galduróz JCF, Noto AR, Nappo SA, Carlini EA. Uso de drogas psicotrópicas no Brasil: pesquisa domiciliar envolvendo as 107 maiores cidades do país - 2001. Rev Latino Am Enfermagem. 2005; 13:888-95.

3. Carlini EA, Galduróz JC, Noto AR, Carlini CM, Oliveira LG, Nappo AS, et al. II Levantamento domiciliar sobre o uso de drogas psicotrópicas no Brasil: estudo envolvendo as 108 maiores cidades do país - 2005. São Paulo: Páginas \& Letras; 2007.

4. Carvalho LF, Dimenstein M. O modelo de atenção à saúde e o uso de ansiolíticos entre mulheres. Estud Psicol. 2004;9:121-9.

5. Telles Filho PCP, Chagas AR, Pinheiro MLP, Lima AMJ, Durão AMS. Utilização de benzodiazepínicos por idosos de uma estratégia de saúde da família: implicações para enfermagem. Esc Anna Nery. 2011;15:581-6.

6. Authier N, Balayssac D, Sautereau M, Zangarelli A, Courty $P$, Somogyi AA, et al. Benzodiazepine dependence: focus on withdrawal syndrome. Ann Pharm Fr. 2009;67:408-13.

7. Rang HP, Dale MM. Farmacologia. $6^{a}$ ed. Rio de Janeiro: Elsevier; 2006.

8. Oga S. Fundamentos de toxicologia. $3^{a}$ ed. São Paulo: Atheneu; 2008.

9. Vieira FS. Possibilidades de contribuição do farmacêutico para a promoção da saúde. Cienc Saude Coletiva. 2007;12:213-20.

10. Greene RJ, Harris ND. Patologia e terapêuticas para farmacêuticos: bases para a prática da farmácia clínica. $3^{a}$ ed. Porto Alegre: Artmed; 2012

11. Jiang Z, Guo H, Zhu Z, Li Z, Wu Y. An epidemiological survey on use and abuse of antianxiety drugs among Beijing residents. Chinese Med J. 1996;109:801-6.

12. Hamilton $\mathrm{M}$. The assessment of anxiety states by rating. $\mathrm{Br}$ J Med Psychol. 1959;32:50-5.

13. Kan CC, Breteler MH, Van Der Ven AH, Zitman FG. Crossvalidation of the benzodiazepine dependence self-report questionnaire in outpatient benzodiazepine users. Compr Psychiatry. 2001;42:433-9.

14. World Health Organization (WHO), Collaborating Centre for Drug Statistics Methodology. Anatomical Therapeutic Chemical ATC/ DDD Index 2013 [Internet]. 2014 [cited 2015 Jun]. whocc.no/ atc_ddd_index/

15. Rodrigues MAP, Facchini LA, Lima MS de. Modificações nos padrões de consumo de psicofármacos em localidade do sul do Brasil. Rev Saude Publica. 2006;40:107-14.

16. Nogueira Filho AM. O perfil de idosos em uso de benzodiazepínicos de uma equipe de atenção primária à saúde [dissertação]. Belo Horizonte: Universidade Federal de Minas Gerais; 2011.

17. Firmino KF, Abreu MHNG de, Perini E, Magalhaes SMS. Utilização de benzodiazepínicos no Serviço Municipal de Saúde de Coronel Fabriciano, Minas Gerais. Cienc Saude Coletiva . 2012;17:15766.

18. Pereira L, Freitas O, Queiroz Netto M. Antidepressivos e benzodiazepínicos: estudo sobre o uso racional entre usuários do SUS em Ribeirão Preto-SP. Rev Cienc Farm Basica Apl. 2012;33:77-81.

19. Kinrys G, Wygant LE. Transtornos de ansiedade em mulheres: gênero influência o tratamento? Rev Bras Psiquiatr. 2005; 27:S43-S50.

20. Andrade MF, Andrade RCG de, Santos V dos. Prescrição de psicotrópicos: avaliação das informações contidas em receitas e notificações. Rev Bras Cienc Farm. 2004;40:471-9.

21. Galleguillos TU, Risco LN, Garay JLS, Gonzáles MA, Vogel MM. Tendencia del uso de benzodiazepinas en uma muestra de consultantes en atención primaria. Rev Med Chile. 2003;131:53540.

22. Huf G, Lopes CS, Rozenfeld S. O uso prolongado de benzodiazepínicos em mulheres de um centro de convivência para idosos. Cad Saude Publica. 2000;16:351-62.

23. Bae JM, Koo HW, Jung KO, Park BJ. A cohort study on the association between psychotropic and hip fractures in Korean elderly women. J Korean Med Sci. 2002;17:65-70.

24. Fick DM, Cooper JW, Wade WE, Waller JL, Maclen R, Beers $\mathrm{MH}$. Updating the Beers criteria for potentially inappropriate medication use in older adults. Arch Inter Med. 2003;163:271624.

25. Escrivá RF, Pérez AD, Lumbreras CG, Molina JP, Sanz TC, Corral MAS. Prescripción de benzodiacepinas en un centro de 
salud: prevalencia, cómo es su consumo y características del consumidor. Aten Primaria. 2000;25:107-10.

26. Veronese A, Garatti M, Cipriani A, Barbui C. Benzodiazepine use in the real world of psychiatric practice: low-dose, long-term drug taking and low rates of treatment discontinuation. Eur J Clin Pharmacol. 2007;63:867-73.

27. Nordon DG, Akamine K, Novo NF, Hübner CVK. Características do uso de benzodiazepínicos por mulheres que buscavam tratamento na atenção primária. Rev Psiquiatr Rio Gd Sul. 2009;13:152-8.

28. Almeida LM de, Coutinho E daSF, Pepe VLE. Consumo de psicofármacos em uma região administrativa do Rio de Janeiro: a Ilha do Governador. Cad Saude Publica. 1994;10:5-16.

29. Brasil, Ministério da Saúde. Relação Nacional de Medicamentos Essenciais (RENAME). 2010 [cited 2015 Apr]. bvsms.saude.gov. br/bvs/publicacoes/rename_2010.pdf

30. Lima $M C P$ Menezes $P R$, Carandina $L$ Cesar CLG Barros MBA, Goldbaum M. Transtornos mentais comuns e uso de psicofármacos: impacto das condições socioeconômicas. Rev Saude Publica. 2008;42:717-23.

31. Brasil, Ministério da Saúde. Secretaria de Atenção à Saúde, Departamento de Atenção Básica. Política Nacional de Atenção Básica [Internet]. 2012 [cited 2015 May]. 189.28.128.100/dab/ docs/publicacoes/geral/pnab.pdf

32. Brasil, Ministério da Saúde. Portaria n. o 336/GM de 19 de fevereiro de 2002: Estabelece CAPS I, CAPS II, CAPS III, CAPS i II e CAPS ad II [Internet]. [cited 2015 Jun]. dtr2004. saude.gov.br/susdeaz/legislacao/arquivo/39_Portaria_336_ de_19_02_2002.pdf saude.mg.gov.br/index.php?option=com_ gmg\&controller $=$ document\&id $=838$

33. Nomura K, Nakao M, Sato M, Yano E. Regular prescriptions for benzodiazepines: a cross-sectional study of outpatients at a university hospital. Intern Med. 2006;45:1279-83.

34. Brasil, Ministério da Saúde, Secretaria de Assistência à Saúde, Departamento de Assistência e Promoção à Saúde. Coordenação Saúde Mental. O uso dos psicofármacos na clínica. Brasília: Ministério da Saúde; 1994.

35. Ford C, Kay R, Barjolin JC. Guidance on prescribing benzodiazepines to drugs users in primary care substance misuse management in general practice [Internet]. 2005 Oct [cited 2015 Jun]. starp.org.uk/wp-content/uploads/2012/06/Prescribing_ benzos_to_Drug_Users_guidance006.pdf

36. Béria JU. Prescrição de medicamentos. Medicina ambulatorial: condutas clínicas em atenção primária. Porto Alegre: Artmed; 2004.
37. Carlini E, Galduroz JCF, Noto AR, Nappo SA. I Levantamento domiciliar sobre o uso de drogas psicotrópicas no Brasil - Estudo envolvendo as 107 maiores cidades do país - 2001 [Internet]. São Paulo: Universidade Federal de São Paulo, Centro Brasileiro de Informações sobre Drogas Psicotrópicas, Secretaria Nacional Antidrogas; 2002 [cited 2015 Apr]. unifesp.br/dpsicobio/cebrid/ levantamento_brasil/parte_1.pdf

38. Kan CC, Hilberink SR, Breteler MH. Determination of the main risk factors for benzodiazepine dependence using a multivariate and multidimensional approach. Compr Psychiatry. 2004;45:88-94.

39. Minaya O, Ugalde O, Fresán A. Uso inapropiado de fármacos de prescripción: dependencia a benzodiazepinas en adultos mayores. Salud Ment. 2009;32:405-11.

40. Wafford KA. GABAA receptor subtypes: any clues to the mechanism of benzodiazepine dependence? Curr Opin Pharmacol. 2005;5:47-52.

41. Golan D, Tashjian A, Armstrong E, Armstrong A. Princípios de farmacologia. 2. Rio de Janeiro: Guanabara Koogan; 2009.

42. Lamoure J. Which antidepressants treat comorbid anxiety and depression [Internet]? 2009 [cited 2015 May]. medscape.com/ viewarticle/711111

43. Furukawa TA, Streiner DL, Young LT. Antidepressants plus benzodiazepines for major depression. Cochrane Database Syst Rev. 2001;(2):CD001026.

44. Kanba S. Psychopharmacology for the clinician psychopharmacologie pratique. J Psychiatry Neurosci. 2004;29:485.

45. Guimarães FS. Hipnóticos e ansiolíticos. In: Fuchs FD, Wannmacher L. Farmacologia clínica. $4^{a}$ ed. Rio de Janeiro: Guanabara Koogan; 2010. p. 61-82.

46. Rickels K, DeMartinis N, Rynn M, Mandos L. Pharmacologic strategies for discontinuing benzodiazepine treatment. J Clin Psychopharmacol. 1999;19:12S-6S.

47. Sweetman SC. Martindale: the complete drug reference. 34rd ed. London: Pharmaceutical Press; 2005.

\section{Correspondence:}

Christiane Colet

Departamento de Ciências da Vida, UNIJUÍ

Rua do Comércio, 3000, Bairro Universitário

98700-000 - Ijuí, RS - Brazil

E-mail: christiane.colet@unijui.edu.br 